\title{
THE USE OF INTERACTIVE TRAINING TECHNOLOGIES IN TEACHING ACADEMIC DISCIPLINES FOR STUDENTS OF TOURISM SPECIALITIES
}

\author{
Olena Sushchenko ${ }^{1}$, Olena Akhmedova², Olena Stryzhak ${ }^{3}$ \\ ${ }^{1,2,3}$ Simon Kuznets Kharkiv National University of Economics, Kharkiv, Ukraine \\ e-mails: ${ }^{1}$ helen.sushchenko@gmail.com, ${ }^{2}$ akhmedovayelena@gmail.com, ${ }^{3}$ sssselllennnn@gmail.com
}

Received: 07 October 2020; Accepted: 20 October 2020 Published: 01 January 2021

\begin{abstract}
The article substantiates the expediency of using the interactive training technologies of teaching in the educational process for students of tourism specialities since training of the specialists for tourism sphere is one of the most important issues because the quality of personnel is a key factor of the tourism development. The essence of interactive teaching methods as compared to the traditional ones has been analysed. The advantages and features of using the interactive methods in the educational process which help to achieve learning objectives, enhance motivation to study, mould professional creative thinking, increase students' interest, stimulates teamwork, overcome shyness and insecurity in the real working environment have been highlighted. In the context of the tourism specialists' professional competences formation, a conceptual structure of the training including content blocks, methods of work, expected results has been proposed. On the basis of the interactive teaching technologies, a training concerning the development of an advertising campaign for a tourism company has been developed. Taking into account the specifics of the tourism industry, the authors have suggested a step-by-step running of an advertising campaign of the tourism company including a complex of interconnected advertising activities developed in accordance with the company's marketing program, covering a certain period of time and aimed at a given target audience in order to provoke a reaction that helps the company solve its strategic and tactical tasks. The article also highlights the advantages and disadvantages of advertising in tourism industry, its effectiveness in different media.
\end{abstract}

Keywords: tourism industry, interactive teaching methods, professional competence, advertising campaign, training.

JEL classification: $M 37, Z 32, Z 39$

\section{Citation:}

Sushchenko, O., Akhmedova, O., Stryzhak, O. (2021). The use of interactive training technologies in teaching academic disciplines for students of tourism specialities. Access to science, business, innovation in digital economy, ACCESS Press, 2(1): 28-39. https://doi.org/10.46656/access.2021.2.1(3)

\section{INTRODUCTION}

Intensification of competition in the context of global economy does not only urge the development and creation of modern tourism products but also requires the development of measures of these products market promotion (Lukjanova \& Odinokova, 2020). The positions of Ukrainian tourism companies at the tourism services global market is weakening. This is not only caused by insufficient investments and a corresponding lag in the service sphere, inadequate state support, a general economic slowdown caused by prolonged hostilities in the east of Ukraine, depreciation of the hryvnya and a general decrease in consumer demand, but also by insufficient attention of the top management of enterprises of the tourism industry to the issues of advertising the product they propose. 
Competent market promotion of the tourism product, gaining consumer preferences, building an effective sales network largely depend on the future specialist's competencies that are formed during the process of education. In this context, the issues of training of specialists whose skills and knowledge meet the modern requirements of the tourism industry become especially relevant. Standard forms and methods of teaching in the tourism field do not sufficiently contribute to the specialists' professional competencies formation.

In the contemporary conditions of global tourism business informatization such interactive methods of teaching as trainings, business simulations, business games, methods of the specific situations analysis, case studies, projects, etc. become really important. The application of the up-to-date interactive learning technologies allows students to develop professional competences and to bring them closer to real conditions, situations, to help using the accumulated theoretical knowledge in practice, to adapt the acquired knowledge and skills in accordance with the conditions of the modern business functioning.

\section{Methodology}

The priority direction of contemporary education is an increasing role of electronic educational and methodical materials for different specialities. They do not only ensure performing of the interactive teaching and learning tasks but also have a special functional load as an additional tool for the formation of the students' subject knowledge and skills as well as optimization of the teachers' professional activity, creation of conditions for their creative potential (Shahina, 2017)

Along with the conventional types of teaching, the scientists research positive and negative aspects of elearning, distance learning and mixed learning. Mixed learning is considered as the most adequate to the requirements of Ukraine's development within the framework of European education (Diachok et al, 2020; Zagorodnya et al, 2020; Petrenko, 2017) as it strengthens a student's orientation, increases the number of students involved in this type of learning, enhances the interaction between a teacher and a student in virtual environment, increases student's autonomy through independent work with a large number of the Internet databases, personalizes learning process. Mixed learning is a model of using informational and educational resources in conventional teaching using the elements of distance learning, practiced as an element of fulltime learning during the students' in-class and independent work. Consequently, mixed learning inherits the elements of distance learning, but in turn eliminates its disadvantages (Kobysia, 2017).

One of the most widely used platforms for mixed and e-learning is LMS Moodle which is free of charge, can be easily edited and modified according to the needs, provides a possibility to learn and teach in the synchronised and asynchronous modes; offers a wide range of network testing; etc. Introduction of the content methods and Moodle information-based online forms of learning to the traditional vocational education is provided with the use of distance courses the structure of which involves step-by-step study of the educational themes in a modular way. Forms and methods are defined for each of the stages of modular learning and involve a combination of individual, networking and classroom activities (Bolubash, 2013). 
New methods of testing and grading of the students' knowledge are offered to fully estimate their progress during the e-learning (Bilousova, et al, 2013). Computer testing allows the lecturers receive a wholesome and comprehensive outlook of the students' skills and abilities provided by the unconditional testing quality.

Consequently, the above stated underlines the necessity for the improvement of professional competence of the university lecturers conditioned by the informatization of education, introduction of distance and elearning (Popova \& Verdenhofa, 2015; Popova, 2015; Linde \& Petrova, 2018). In this context, D. Bodnenko (2013) analyses a new paradigm of the teacher's professional competence concept, identifies and describes informational and communicational professional skills to provide a high level of education. It is important to mention here that $75.40 \%$ of lecturers actively use information and communication technologies for training bachelors of different specialities (Dyshko et al, 2017). Thus, Skype, Viber are used for videoconferencing, Moodle, Dokeos, ATutor, "Blackboard", "Prometheus" are used as platforms for electronic education. To support the teaching staff in this direction, various types of workshops for teachers have to be proposed (Veselinovskaa et al, 2010).

The issues of the interactive methods usage, elements of which are trainings of different types, are receiving a lot of attention nowadays. In particular, Dolbneva D. (2014), Bodruh N. (2014), Kreps T. (2018), Fedorenko N. (2015) consider various aspects of the interactive teaching of the academic disciplines in the higher educational institutions. These authors insist that these methods can and should be widely used for the majority of specialities. In this respect a high level of material prepared, logical and well thought out structure of the interactive lesson comes to the fore as the teacher ceases to be central in the teaching process, he / she only regulates the process, monitors and consults (Pozdeeva et al, 2015). Besides, the lecturers try to analyse and assess the results of interactive teaching compared to the conventional one (Usmanova et al, 2015).

It is obvious that a strong theoretical basis for the use of interactive methods of teaching in the educational process has already been formed by the moment, however, in our opinion, the issue of using interactive training technologies for teaching academic subjects in higher educational institutions needs further research and development. (Bodnar, S., Mirkovich, I., Koval, V., 2019).

In the general meaning, training is a method of active learning aimed at developing knowledge, skills and abilities as well as social attitudes.

In order to develop practical skills and competences of bachelors of the tourism speciality of full-time and correspondence forms of study for developing an advertising campaign for a tourism company, the authors have developed a training "8 steps to creating an advertising campaign for a tourism company". The training is interdisciplinary and takes into account the professional competences in the disciplines "Management", "Marketing", "Economics of an enterprise".

The following tasks are solved during the training:

- analysis of the external environment of enterprises of the tourism industry; 
- determination of the target segment of the tourism services market based on the basis of the analysis of the main consumers and dealers of tourism product;

- formulation of the objectives and main tasks of the prospective advertising campaign;

- development of the advertising campaign strategy, its concept, corporate image, slogan, substantiation of the uniqueness of the trade offer;

- consideration of the nature of the prospective advertising campaign defining its main directions in the B2B sector (highlighting the main consumers, establishing direct contacts, participating in exhibitions, fairs, meetings with business representatives) and the tourism services market (the terms of carrying out, territorial, demographic and age coverage, intensity);

- estimation of the costs of advertising activities and evaluating their likely effectiveness.

The training involves the use of such interactive learning methods as active game forms, problem solving exercises and business cases, group discussions, brainstorming, imitation modelling and presentation of the group work results.

The use of the abovementioned interactive methods during the training allows enhancing the students' cognitive activity, develop critical thinking skills, analysis of situations, increase the motivation to study the discipline, stimulates the development of skills on searching and using relevant information, develops the ability to use information and communication technologies, improves communication skills and creates a supportive working environment in the workgroup.

\section{Results}

Educational institutions distinguish between traditional teaching methods and interactive ones. It is well known that teaching methods are a joint activity of a lecturer and the students, aimed at mastering their knowledge, skills and abilities.

As a rule, traditional teaching methods include: lectures (introductory, preparatory, overview, lecturespresentations, mini-lectures, etc.), conversations, explanations, consultations, quizzes, demonstrations (demonstrations of the methods, real objects, slides, posters, videos etc.), exercises (oral, written, calculatory), practical exercises according to an example, independent work with literature and others.

The essence of interactive teaching is revealed through the interpretation of the term "interact" which generally defines the ability to mutual activity.

The interactive model views teaching as a special form of cognitive activity organization that has a specific, intended purpose - to create comfortable learning conditions under which each student feels his / her success and intellectual ability and acts as a subject of teaching (Akhmedova, 2014).

The use of interactive teaching technologies in the educational process is presented by: problematic lectures, lectures-press-conferences, binary lectures, lectures-shows, group projects, press conferences, round tables, discussions, briefings, guest seminars (when specialists are invited), business and didactic roleplaying games, case studies, trainings (corporate, psychological, business training, etc.). 
Interactive teaching is:

- teaching based on the student's interaction with the learning environment, the learning space, which serves as an area of mastered experience";

- teaching based on the psychology of human relationships and interactions";

- teaching which is understood as a joint process of cognition, where knowledge is obtained in joint activities through dialogue, polylogue".

The main difference of interactive teaching from traditional one is its orientation to the problem solving, developing the ability to be personally responsible for the decisions made, understanding the motives and interests of other participants. Interactive teaching methods allow to not only study, find out, consolidate theoretical material, but also to form the students' skills to think independently, to act, to conduct scientific debate, to think critically, to be able to adapt to changing environmental conditions, to make decisions and analyse their consequences.

The main objective of interactive teaching is to develop students' ability to apply their knowledge in practice for solving real-world problems. Therefore, the important task of interactive teaching is to give students the opportunity to express their opinions, to demonstrate their individuality, to remain interested in acquiring knowledge in the chosen profession. This does not exclude the lectures, but often lectures are overloaded with terminology, statistics and are difficult to remember. In an era of rapid technological change, the students' passive knowledge acquisition is the cause of boredom and frustration and very often leads to a loss of interest not only in the subject, but also in the professional activity in general. Thus, there is a growing necessity to stimulate students' interest in learning by creating the real life contexts, providing them with diverse and multi-faceted tasks. After all, in order to be ready to adapt to the changes occurring in the workplace and the environment, future professionals must have the appropriate professional skills. Nowadays, specialists of the tourism industry should not only be competent in their field, but also be managers, leaders, foresee the prospects of business development, be able to work with people, understand the peculiarities of the market economy functioning, etc. (Popova et al., 2020)

Interactive teaching involves a constant change of types of educational interaction when a student and a teacher are equal participants. During the training, a teacher can fully use his / her creativity for improvisation within a given topic or imitations of the life and production situations. Improvisation during the training session stimulates students' vigilance and flexibility, and, at the same time, poses some challenges for the teacher, as it is not always possible to predict what students would expect in the process of a problem situation modelling.

Reactive teaching (when the teacher immediately responds to students' questions, comments) is significantly different from the traditional one, when questions and answers are focused only on a clearly stated academic subject, by the additional, unexpected, and immediate attachment to the context, professional or life situation. The atmosphere of this type stimulates formation of the practical skills and 
abilities, creates an atmosphere of cooperation, enhances students' motivation to acquire knowledge, promotes the development of creative abilities and communication skills, etc.

It is obvious that successful sale of tourism services and tourism product largely depends on the quality but the potential consumer awareness about these services and products is also of great importance. Therefore, the fame of a tourism company, maintaining its positive image as a reliable business partner is impossible without advertising. Advertising does not only inform the consumer about the products, but also creates a demand, motivates a potential buyer to purchasing.

Advertising is a system of paid activities aimed at bringing specially prepared, expertly processed information about a product (services) and its manufacturer (supplier) to the consumer. Orekhov S.A. (2011) characterizes advertising as any paid form of communication with a potential consumer audience, representing a product or service, forming any images, subconscious associations with the consumer, affecting consumer's final choice.

In the Act of Ukraine "On Advertising" advertising is defined as information about a person or product, distributed in any form and by any means and intended to create or maintain awareness of advertising consumers and their interest concerning these persons or goods. Similar definitions of advertising are presented in the Act of the Republic of Belarus "On Advertising", where advertising is understood as information about the object of advertising, disseminated in any form by any means, intended for an indefinite number of persons (consumers of advertising), aimed at attracting attention to the object of advertising, creating or maintaining interest in it and (or) its market promotion.

Like in any other economic industry, in the tourism industry advertising performs the following functions: 1) first of all, informational - is a statement about existence of a tourism product, company, includes a description of the main quantitative and qualitative parameters and features, as far as the product and services of this industry are both $\mathrm{B} 2 \mathrm{~B}$ and $\mathrm{B} 2 \mathrm{C}$ oriented; 2) stimulating - is the stimulation and development of the client's needs in the tourism product and services; 3) motivational - after realizing the need for tourism product, there is an incentive to action: buying a product or service, receiving information.

An advertising campaign is a complex of interconnected advertising activities developed in accordance with the company's marketing program, covering a certain period of time and aimed at a given target audience in order to provoke a reaction that helps the company solve its strategic or tactical tasks.

The development of an advertising campaign for a tourism company should not be only aimed at increasing sales of the company's product and services, but also at creating a positive image in the society, forming an identity of a reliable business partner. In each area, advertising has certain features, in particular, in the tourism industry the object of advertising is primarily the $\mathrm{B} 2 \mathrm{C}$ sector, therefore, in this industry advertising should be, primarily, informative. However, given the wide range and type of products of the tourism industry, which includes tourism services as well, one cannot ignore traditional consumer channels for product promotion. 
Print advertising - Information letters, catalogues, leaflets, posters, booklets, brochures, calendars

- budget ways of disseminating information (except catalogues); wide channels of dissemination (mailing, distribution in various places) and high penetration capability

- targeting a specific product; selectivity (does not affect a wide audience)

Press advertising - Advertisements, articles, graphic pictures in newspapers and magazines

- an inexpensive way to attract the target audience due to the media outlet specialization; good local market coverage; illustrative form allows conveying complete information to the consumer of the tourism product; attractive tourism destination and proposal enhances the impact on the consumer; the possibility to receive the feedback to consumers through coupons

- a limited scope of attracting customers; short lifetime of the advertisements; a limited audience of the "secondary" reader

Audiovisual advertising - commercials, audio and video films, slide films, screensavers, on-air ads, advertising in cinemas, hidden advertising (in films and broadcasts)

- wide coverage of all segments of the population; visual and audio contact that arouses emotions; efficiency and relevance of the advertising messages; targeting by time, interests (placing ads in certain programs) and the number of contacts with the target audience; the possibility to quickly modify an advertising message; high repeatability of advertising messages

- high price; transience of an advertising contact; quickness and obtrusiveness of advertising messages; the audience's growing hostility

Internet advertising - Web sites, banner advertising, emailing, SEO promotion

- audience targeting feedback efficiency; real-time sales opportunity

- the user's ability to completely block the ad; the need for ongoing support and updates; high cost of an advertising campaign

Outdoor advertising - billboard advertising, point of sale advertising, transport advertising

- wide coverage of the advertising audience; attracting attention and strong influence on consumers due to the visual effects; targeting a specific audience depends on the location, region and direction; cheaper than television and radio advertising

- high cost; short contact time; low memory retention of the advertising message; the complexity of registration and formalisation; is of a complementary character

Direct mail advertising - Leaflets, booklets, letters

- selective, because it is sent to certain individuals; is of a personal character; high degree of exposure; provides feedback

- the message may be lost or ignored, recipients may change addresses; difficulty of consumers targeting; an image of "waste paper"

Specialty advertising - branded souvenirs, serial souvenir products, business gifts, branded packaging materials

- present advertising information in everyday life; low cost, originality and attractiveness; usefulness for the user

- low target audience coverage

\section{Participation in exhibitions - Exhibitions, fairs, presentations}

- tourism product presentation; visual demonstration of new products; establishing contacts; analysis of the competitors; attracting intermediaries is time-consuming and expensive

Point-of-sale advertising - posters, stickers, large-format transparencies, etc.

- design of the trading floors and display stands; low cost, visibility and attractiveness

- low target audience coverage

Non-traditional media - Sponsorship, event marketing, "guerrilla" advertising, transit advertising, word of mouth advertising, mass text messaging

- unexpected places for advertising to attract attention; memorability; low costs

- low target audience coverage; episodic effect; negative reviews spread faster than positive

Fig. 1. Advantages and disadvantages of different forms of advertising in tourism industry

Source: compiled by the authors 
During the training, the properties, competitive advantages and features of the tourism company's products are determined as they are to be offered for sale during the advertising campaign. Highlighted features of tourism products are the basis for choosing the appropriate channels of market promotion.

The main means of advertising dissemination in the tourism business, as well as their advantages and disadvantages are presented in Fig. 1.

Further, students are invited to develop a detailed plan of the advertising campaign. During the training, the need for an advertising campaign is justified, its objectives and main tasks are determined, the desired results are indicated. The competitive advantages of both the tourism company itself and the tourism product that will be advertised are preliminary evaluated. Depending on this, elements of the corporate identity of the advertising campaign such as a logo, slogan, corporate colours and the like are developed, emphasising uniqueness, the attractiveness criteria and the differences of the advertising proposal.

In addition, the planned costs of the advertising campaign are calculated with the appropriate distribution of funds on the channels for the tourism product promotion and the means of advertising dissemination. Accordingly, the possibilities of using various types of advertising are evaluated, first of all, by the degree of coverage of the target market segment, its costs, intensity, time and frequency of advertisements in the selected advertising media.

In conclusion, a preliminary assessment of the advertising campaign effectiveness for each media and the entire campaign is carried out; the analysis of the degree of the audience coverage is conducted and is also compared with the goals of the advertising campaign. The real increase of the consumer requests is analysed in comparison with the planned sales volumes of the tourism product and services, the increase of the tourism company rating and image improvement are assessed, etc.

Thus, a step-by-step detailed plan of an advertising campaign of the tourism company can be used by the tourism entities as a basis for the implementation of advertising means for the tourism product and services promotion.

\section{CONCLUSION}

Thus, organizing and conducting a training for students of the tourism specialities demonstrates the following advantages of the interactive teaching technologies:

1) the interactive technologies can be combined with the traditional methods and forms of teaching, following the logic of the educational process;

2) the integration of the interactive methods in the process of education increases effectiveness of the traditional teaching by formation the skills which help applying theoretical knowledge in the situations close to real conditions;

3) the interactive technologies contribute to the formation of the future specialists' professional competencies as well as communication skills, ability to work in a team, stimulate the development of creativity. 
During the training with the use of the interactive technologies, students of the tourism specialities acquire competencies in the analysis of the market environment of the tourism industry enterprises; learn to formulate strategies, objectives, tasks, nature and main activities of a tourism company's advertising campaign, segment the consumers of the tourism product by selected criteria, estimate the costs of the advertising activities, etc.

The structure of the training according to the content blocks, methods of work, as well as its expected results are presented in Fig. 2.
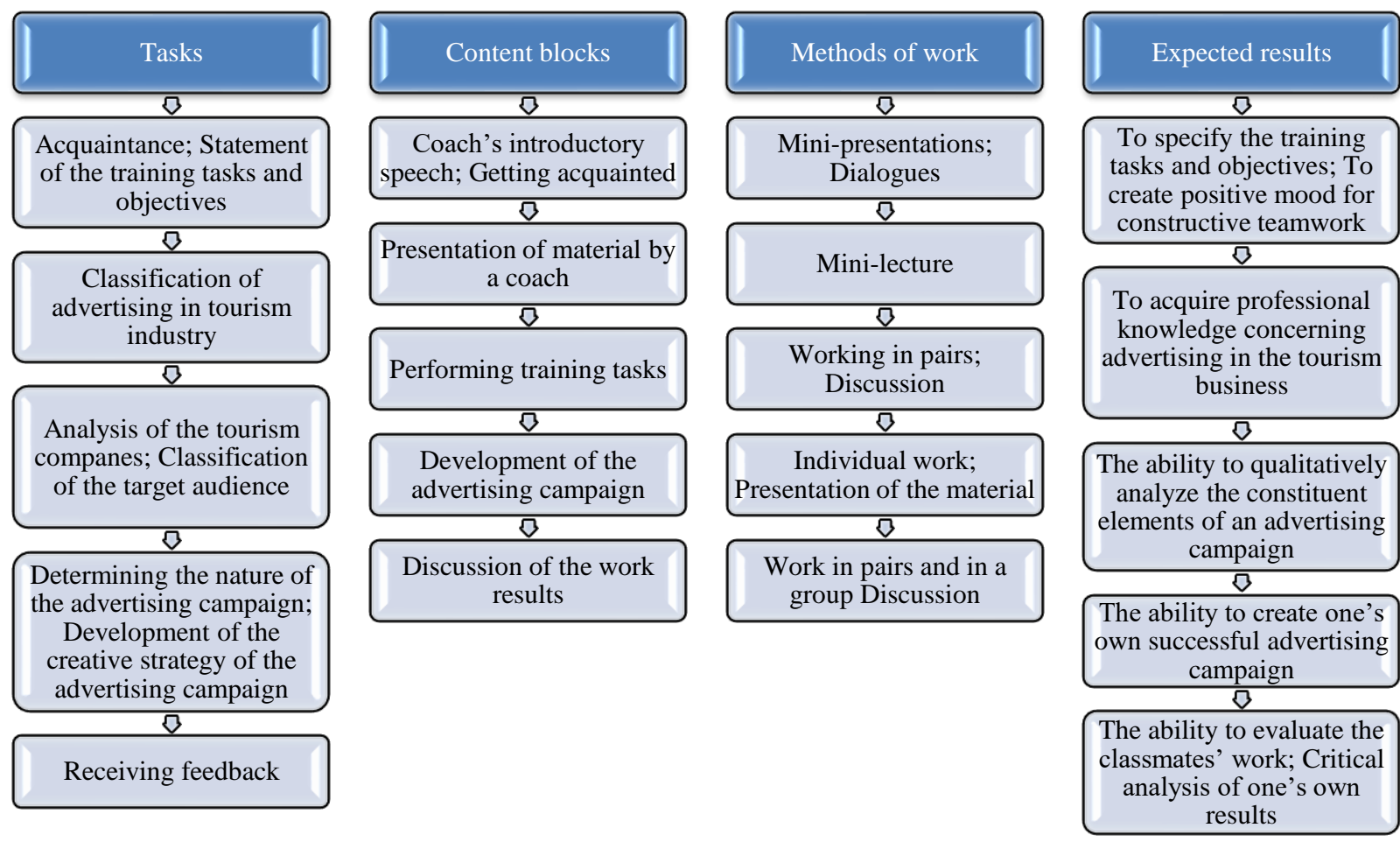

Figure 2. The content structure of the training

Source: compiled by the authors

In addition, the results of the analysis of the means of advertising dissemination in tourism industry are presented in the article.

The authors believe that the interactive training technologies will help the prospective specialists in the field of tourism industry acquire complex understanding of current problems of the tourism industry development, contribute to the skills formation using advanced domestic and foreign experience in the activities of the tourism enterprises.

\section{Conflict of interests}

The authors declare no conflict of interest. 


\section{References}

Advertising and sales promotion. The essence of advertising and its main features. Retrieved August 17, 2020, from http://megalektsii.ru/s56216t1.html.

Akhmedova, O. (2014) The use of simulation methods of teaching future bachelors in tourism services. Donetsk state university of management, V 5, p. 25-30.

Bilousova, L., Kolgatin, O., Kolgatina, L. (2013) Pedagogical Diagnostics with Use of Computer Technologies. CEUR Workshop Proceedings 1000, http://ceurws.org/Vol-1000/ICTERI-2013-p-209-220.pdf.

Bodnar, S., Mirkovich, I., Koval, V. (2019). Human capital development in Ukrainian education system by means of language integrated teaching. Dilemas contemporaneos-educacion politica y valores, Vol 7 (SI), 14.

Bodnenko, D. (2013) The Role of Informatization in the Change of Higher School Tasks: the Impact on the Professional Teacher Competences // ICT in Education, Research and Industrial Applications: Integration, Harmonization and Knowledge Transfer, Vol-848, Vol-716281-287, pp. 281-287.

Bodruh, N. (2014) Using Interactive Technologies Forming Pedagogical Skills while Learning Humanitarian Disciplines. Vytoky pedahohichnoyi maysternosti, Vol. 13.

Bolubash, N. (2013) Organizational-methodical Aspects of Training on the Basis of Information Environment Moodle. Information technologies and teaching methods, №1 (33), available at: http://journal.iitta.gov.ua.

Diachok, N., Chernukha, N., Tokaruk, L., Udovenko, I., Petrova, M. 2020. Practical-oriented concept as a principle of professional education of the future professionals. International Journal of Higher Education, Vol. 9, No. 4, August 2020, pp.272-282, https://doi.org/10.5430/ijhe.v9n4p272

Dolbneva, D. (2014) Interactive Teaching Methods: the Nature and the Need to Use in Training of Specialists in Accounting and Auditing at the University of Ukraine. Scientific Bulletin of NLTU of Ukraine, Vol. 24.1.

Dyshko, O., Zubekhina, T., Pavlyshyna, N. (2017) Information and Communication Technologies in the Organization of Bachelors' E-learning (using the example of specialities "Tourism" and "Social Work"). Information technologies and teaching methods, Vol. 59, №3, pp. 76-86.

Fedorenko, N. (2015) Interactive Learning in Higher Education: Effective use of Training Technologies. Topical Issues of Sociology, Psychology, Pedagogy, №1 (26), pp. 155-160.

Kreps, T. (2018) Application of Modern Educational Technologies when Teaching Economic Disciplines. Scientific bulletin of the Southern Institute of Management. No. 4, pp.124-131.

Kobysia, A. (2017) Information Educational Environment as a Platform for Implementing Blended Learning in Higher Education Institutions. Information technologies and teaching methods, Vol. 57, №1, pp.75-81.

Lazarova, T., Zhelyazkova, V., Vazov, R. (2015). Innovation leadership as a key concept in entrepreneurship. The 8th International Conference for Entrepreneurship, Innovation and Regional Development. 18th and 19th June 2015 Conference proceedings, University of Sheffield

Linde I.,Petrova M. (2018).The challenges of Formalization and Modeling of Higher Education Institutions in the 21st century.CBU International Conference Proceedings 2018: Innovations in Science and Education. 303-308. https://doi.org/10.12955/cbup.v6.1173

Lukjanova, L., Odinokova, T. (2020). Innovations as the main challenge in the field of health tourism in Latvia. Access journal: Access to science, business, innovation in digital economy, ACCESS Press, 1(1): 39-52. DOI: https://doi.org/10.46656/access.2020.1.1(3)

Nenkov, N., Dyachenko, Y., Petrova, M. (2017) Intelligent and Cognitive Technologies in Education of International Economic Relations Students and Human Resource Development in Enterprises: Methodology in Language, "European Journal of Sustainable Development", Vol 6, No.4, pp. 353-360, DOI: 10.14207/ejsd.2017.v6.n4.p353.

Orekhov, S., Romanova, M. (2011) Production management: textbook. M.: YEAOI.

Petrenko, S. (2017) Optimization and Analysis of the Results of Using IMS Moodle in the Mixed Learning System in University. Information technologies and teaching methods, Vol. 61, №5, pp. 141-150. 
Popova,O., Koval, V., Mikhno, I., Tarasov, I., Asaulenko, N., Filipishyna, L. (2020). Assessments of national tourism development in terms of sustainability and inclusiveness. Journal of Geology, Geography and Geoecology, Vol. 2, № 2, pp. 377-386. https://doi.org/10.15421/112033

Popova L., Verdenhofa O. (2015). Instruments for regulation of the education market. Compilation from the International scientific conference "Pedagogical education - traditions and modernity", V. Tarnovo, 20 - 21 November 2015. Compiler: R. Hristova - Kotseva. Veliko Tarnovo: I and B, 2015. ISBN 978-619-7281-01-9

Popova, L. (2015). Motivation for active use of electronic services in the educational system. E-government in the regions: challenges and prospects: compilation of participants at the International scientific internet-conference «E-government in the regions: challenges and prospects» (18-19 December 2014). / branch of the Kuzbass State Technical University in the town of Belovo. - Belovo: Publishing house of the branch of the Kuzbass State Technical University in the town of Belovo, Russia, ISBN 978-619-208-011-2. - 206 p. /pp. 148-151.

Pozdeeva, S., Obskov, A. (2015) Justification of the Main Pedagogical Conditions of Interactive Teaching a Foreign Language in High School. Procedia - Social and Behavioral Sciences 206.

Shahina, I. (2017) Organization of Educational Process Using Electronic Educational-methodical Complexes for Preparation Computer Technologies Specialists. Information technologies and teaching methods, Vol. 58, №2, pp.141-154.

Sushchenko, O., Trunina, I., Basyuk D., and Pokolodna M. (2019) Coaching as Education Technology on Electrical Engineering Education. IEEE International Conference on Modern Electrical and Energy Systems (MEES), Kremenchuk, Ukraine, 2019, pp. 426-429, doi: 10.1109/MEES.2019.8896507.

The Act of the Republic of Belarus "On Advertising” // National register of legal acts of the Republic of Belarus, (2007).

The Act of Ukraine “On Advertising” issued 03.07.1996 № 270/96-VR // Information of the Verkhovna Rada of Ukraine (VVR), N 39, st. 181. (1996).

Usmanova, N., Shindina, T., Basharina, A. (2015) Development and Assessment of Interactive Teaching Approach Impact on Communicative Competence of Bachelors of Economic Universities. Procedia - Social and Behavioral Sciences 214, pp. 66-70.

Uteubayev, T., Petrova M.M., Lyubenova, I. (2018) Training of qualified specialists in the process of their education at the university: the role of the public-private partnership. CBU international conference proceedings 2018: innovations in science and education. Book Series: CBU International Conference Proceedings Pages, pp. 491495.

Veselinovskaa, S., Zivanovika, J., Petrovska, S., Gokika, M. (2010) Interactive learning in programmed teaching of the subject "Based of nature science" at pedagogical faculties in the Republic of Macedonia. Procedia Social and Behavioral Sciences Vol. 2.

Zagorodnya, A., Dichek, N., Chobitko, N., Voznyk, M., Honchar, L., Petrova, M. (2020). Professional training of the economic sector specialists at higher education institutions of the Republic of Poland and Ukraine: criteria of comparison. International Journal of Higher Education, 9(3), 139-144. https://doi.org/10.5430/ijhe.v9n3p139

\section{About the authors}

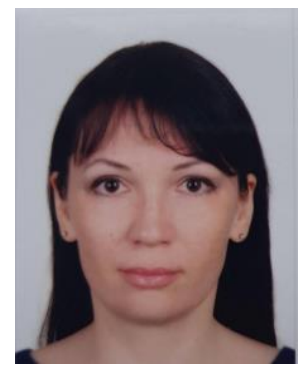

\section{Olena SUSHCHENKO}

Dr.Sc. (Economics), Professor, Simon Kuznets Kharkiv National University of Economics, Kharkiv, Ukraine. Scientific interests: tourism and hospitality, economics and management, international business.

ORCID ID: https://orcid.org/0000-0002-2645-8015 


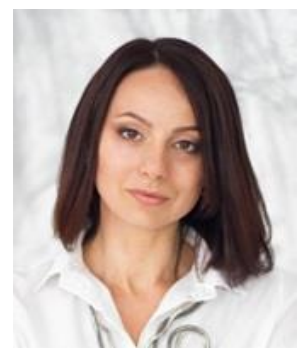

\section{Olena AKHMEDOVA}

PhD in Public Administration, Associate Professor of the Tourism Department, Simon Kuznets Kharkiv National University of Economics, Kharkiv, Ukraine. Research interests: tourism and hospitality, public administration, integration of education, interactive teaching.

ORCID ID: https://orcid.org/0000-0003-1573-7710

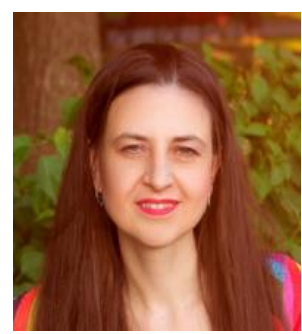

\section{Olena STRYZHAK}

Ph.D. (Economics), Associated Professor, Simon Kuznets Kharkiv National University of Economics, Kharkiv, Ukraine. Scientific interests: institutional problems of tourism activity, institutional aspects of economic development, human development.

ORCID ID: https://orcid.org/0000-0002-9367-9061

Copyright (C) 2020 by author(s) and ACCESS Publishing Press This work is licensed under the Creative Commons Attribution International License (CC BY) 